convexity. First, it may be more probable for higher terraces or beaches to be eroded away than for lower ones. Secondly, if a set of beaches little differing in height is raised to some altitude, they will more often than not be taken together as one beach, as might be indicated by the wide margins given for some of the raised beaches. Both factors will make the left side of the curve steeper than it would originally have been, resulting in giving the curve a tendency to convexity towards the $X$ - and $Y$-axes.

H. J. MacGillavray.

Mineralogical Geological Institute, UTRECht, Holland.

\title{
THE GLACIAL SUCCESSION ON THE NORTH COAST OF NORFOLK.
}

Sir,-By the publication of his paper (Proc. Geol. Assoc., xliii, pt. 3, 1932, 241-271), Dr. Solomon has made another and a valuable contribution to our knowledge of the very complex problem of the glacial succession on the north-east coast of Norfolk. During the last fourteen years I have made very numerous visits to the area dealt with by Dr. Solomon and have carried out a close examination of most of the deposits with which he deals. The object of my excursions to the Norfolk coast has been the excavation and collection of flint implements, and I suppose I am one of those responsible for the finding of these specimens in situ in various beds, of which Dr. Solomon speaks. I fear, also, that I am to be numbered among the archæologists who have indulged, though I trust not, in my case, in an orgiastic manner in the correlating of certain types of implements with these deposits. However, having always proceeded with due care and caution along this difficult path, I am hopeful that my tentative efforts will not be included among those which are condemned by Dr. Solomon as "ill-informed". There is, of course, not much doubt that some of the correlations which have appeared in various publications are of small value. But the archæologists may perhaps be forgiven for this because, after all, if it had not been for their investigations, carried out quite frequently in the face of determined opposition by geologists, the latter to say the least would have experienced considerable difficulty in extricating themselves from the monoglacial morass, and the slough of despond of the post-glacial age of man.

I hope my geological friends will forgive me for reminding them of this historical fact, which appears at times to be in grave danger of being overlooked and forgotten.

There are, however, many things for which archæologists should be thankful ; and I trust I am duly appreciative of Dr. Solomon's statement that, while the implements I have found in the Stone Bed, near Cromer, are not "universally accepted", nevertheless "the bulk of archæological opinion is inclined to accept their 
authenticity". Dr. Solomon states, further, that these flint implements should not be called "Chellian ", "for the dominant type is not the coup de poing but rather a roughly trimmed flake implement. . . ." Now, as to these claims, I would say first of all that, while I do not think that any flint implement should be called by such an unmeaning name as "Chellean", I nevertheless consider that the specimens I have found in the Stone Bed mentioned are as much entitled to that term as are any others to which it is usually applied. For my experience has shown that the "dominant" type of artefact in the Stone Bed under discussion is a coarsely flaked, core hand-axe. And though there may be some room for argument as to whether "Chellean" is a fitting term to apply to a flint implement, the question as to what is the dominant type of artefact in the Stone Bed near Cromer is a matter which can be settled by excavation and observation.

Dr. Solomon claims that the provenance of the ochreous specimens found by me on the foreshore at Cromer and elsewhere is "doubtful ". There are, unfortunately, many doubtful things in archæology, and I suppose that even geology is not entirely exempt from them ; but, as to these ochreous flints, I can at least claim that $I$ have been at considerable pains to make public in detail ${ }^{1}$ my reasons for believing these specimens to have been derived from the Stone Bed. In this view I may, of course, be mistaken, but in any case it is a matter of much importance and I hope that Dr. Solomon will be able to tell us why he thinks the provenance $I$ have claimed for the ochreous flints is doubtful and to what horizon he would himself relegate them. I am sincerely anxious to have this difficult matter elucidated, and shall welcome any scientific criticism he cares to make of my findings. I find myself unable to accept Professor Boswell's claim that the Chellian period "straddled two glacial episodes", though I realize he is perfectly justified in making it, owing to the absurd manner in which archæologists apply the term Chellean to hand-axes of very different types and degrees of antiquity. In my opinion this term should be abolished, but until this happens archæologists should, at least, make some attempt to define its modern meaning. I would suggest that the name "Chellean" should be applied only to hand-axes, often of rostroid form, made by coarse, "free" flaking, in which symmetry of outline is not an outstanding feature, and possessing heavy butts and clearly defined wavy edges. It is evident that Professor Breuil in his recent paper (written in conjunction with Professor Koslowski) "Etudes de stratigraphie paléolithique dans le Nord de la France, la Belgique, et l'Angleterre ", 2 is realizing the necessity of this, and it is to be hoped that this paper marks a further step in putting the archæological house in order. If the term "Chellean " is to be applied in future only to hand-axes such as I have described, then I have no

1 Journal Anthr. Inst., 1921, July to December, 385-418.

2 L'Anthropologie, t. x]i, 1931. 
doubt that these specimens were made in the period, or periods, when the Cromer Forest Bed and the Stone Bed at its base were deposited, that they are to be found in these accumulations and not in those of later date, except in a derived condition. The other more symmetrical, approximately straight-sided hand-axes, made, as to their thin, blade-like anterior portions, by "controlled" flaking, to which also the term "Chellean" is applied by some archæologists, are never found in the deposits mentioned but are to be regarded as "Acheulean" implements belonging to a later interglacial epoch.

I notice that, in his reference to the Baeton Valley Gravel, Dr. Solomon does not mention that flint implements have been found in this deposit. 1 It was from here that half a hand-axe of Acheulean type was discovered, but I did not know that, as claimed by Dr. Solomon, another has been found in the gravel surmounting the cliff at Lighthouse Hill, Cromer.

\section{J. ReId MoIr.}

\section{THE OATLAND (I.O.M.) IGNEOUS COMPLEX. ${ }^{2}$}

SIR,--It has been brought to the notice of the authors of the above that no mention has been made of a paper ${ }^{3}$ published in 1910 , bearing on the same subject. In drawing up a list of works in this connection the usual precautions were taken toinclude everything within the reach of the average reader; and through being unaware of White's work the authors have made an interesting comparison possible, and it is gratifying to find that what was doubtful in their minds is corroborated by this independent investigation. There are no serious differences in the conclusions though the former worker seems convinced that a considerable interval elapsed between the intrusion of the basic and acid phases. Actually this is consistent with the then prevailing view that such contrast in composition could only be brought about by time. If such is the case why then should the granite be disposed concentrically within the basic rock? The influence of heat, greatest in the centre, is known to be of the highest importance in assisting the uprise of the later magma. But should the consolidated mass be entirely cool there is no cause for the second intrusion to follow a particular course and the granite at Oatland gives not the slightest indication of having arisen in anything but a definite channel within the basic rock and through that part which was obviously the hottest before emplacement was effected.

\section{E. A. Gamba.}

1 Proc. P.S.E.A., iii, pt. ii, 219-243.

2 J. H. Taylor and E. A. Gamba, Proc. Geol. Assoc., xliv, 355-377.

3 White, F. W. "Complex of Igneous Rocks at Oatland (Santon) Isle of Man," Proc. Geol. Soc. Yorks, 1910. 